УДК 556.3.06

\title{
ГИДРОГЕОЛОГИЧЕСКИЕ ПРОГНОЗЫ В ЦЕЛЯХ ОСУШЕНИЯ МЕСТОРОЖДЕНИЯ АЛМАЗОВ ИМ. В. ГРИБА
}

\author{
Еланцева Людмила Алексеевна', \\ LAElanceva@novotek15.ru
}

Зайцев Денис Александрович',

Zden86@yandex.ru

Фоменко Сергей Викторович',

SVFomenko@rambler.ru

\author{
' ООО НТЦ «НОВОТЭК», \\ Россия, 308002, г. Белгород, пр. Б. Хмельницкого, 131.
}

Актуальность исследования обусловлена необходимостью вовлечения в промышленное использование весьма сложного в гидрогеологическом отношении месторождения алмазов, на котором добыча руды осуществляется с проведением крупных мероприятий по водопонижению, направленных на создание безопасных условий производства горных работ. Прогнозирование управляемого водопонижения и изменения гидрогеологических условий при эксплуатации месторождения является сложной задачей, требует учета многих природных и горнотехнических факторов и разработки методических приемов ее решения.

Цель: разработка методики и выполнение гидрогеологических прогнозов для эффективного осушения при эксплуатации месторождения алмазов им. В. Гриба.

объекты: осушаемые водоносные горизонты и дренажная система карьера.

Методы: анализ применения численных методов моделирования для исследования процессов фильтрации при осушении месторождений полезных ископаемых, численное моделирование.

Результаты. На основе изучения геолого-гидрогеологических условий месторождения алмазов им. В. Гриба, способа отработки, выделенных осушаемых водоносных подразделений и источников формирования водопритоков к дренажной системе карьера создана численная модель фильтрации подземных вод. Рекомендовано для перехвата части проскока подземных вод в карьер, дренажа падунского водоносного комплекса на участках, где осушение не обеспечивается ВПС, осушение переходной зоны падунских и мезенских отложений осуществлять внутрикарьерными дренажными устройствами. Предложена методика реализации на численной модели внутрикарьерных дрен. Выполнены прогнозные расчеты с целью эффективного осушения месторождения. Методом численного моделирования доказана эффективность применения лучевого дренажа и горизонтальных дренажных скважин для интенсификации осушения падунских отложений в прибортовом массиве карьера, выполнен прогнозный расчет высоты высачивания на бортах карьера с учетом плана развития карьера. Предложены сроки сооружения внутрикарьерных дренажных устройств.

\section{Ключевые слова:}

Управляемое водопонижение, водопонижающие поверхностные скважины, карьерный водоотлив

гидрогеологические прогнозы, численное моделирование, лучевой дренаж, горизонтальные дренажные скважины.

\section{Введение}

В практике гидрогеологического прогнозирования условий осушения месторождений полезных ископаемых, как правило, применяются численные методы моделирования, являющиеся на современном этапе исследований основными методами изучения процессов фильтрации при решении сложных гидрогеологических задач в области осушения месторождений [1-17].

Достоверность и надежность гидрогеологического прогноза зависит от корректности гидрогеологической схематизации и обеспечивается при решении задач осушения месторождений выполнением трех общих принципов: непрерывности осуществления схематизации по мере накопления информации, адаптации расчетных схем, обратной связи схематизации с природными и горнотехническими особенностями изучаемого месторождения [18-20].

Моделирование реализует все три указанные принципа схематизации, позволяет с максимальной эффективностью использовать весь объем имеющейся информации о месторождении в рамках единой численной математической модели.

Гидрогеологическая схематизация осуществляется таким образом, чтобы наряду с идентификацией математической модели данным режимных наблюдений за уровнями подземных вод и водопритоками к дренажной системе карьера обеспечивался инженерный запас в прогнозных оценках.

\section{Краткая характеристика месторождения} алмазов им. В. Гриба

Месторождение алмазов им. В. Гриба (кимберлитовая трубка) перекрыто толщей среднекаменноугольных терригенно-карбонатных пород и рыхлых четвертичных отложений суммарной мощностью 50-80 м и прорывает осадочные терригенные породы рифея и венда мощностью порядка 1150 м $[21,22]$.

Кимберлитовая трубка представляет собой вертикальную залежь с ярко выраженными контурами кратерной и жерловой частей. Кратер диатре- 
мы сложен песчаниками с примесью кимберлитового материала, туфопесчаниками, туфами, туффитами, брекчиями осадочных пород, в нижней части содержит маломощные инъекции кимберлитов. Жерло трубки выполнено туфобрекчиями, ксенотуфобрекчиями и кимберлитами.

В геологическом разрезе четко выделяют два структурных этажа: архей-нижнепротерозойский кристаллический фундамент (гнейсы, амфиболиты, гранатсодержащие гнейсо-граниты) и осадочный чехол, сложенный преимущественно терригенными образованиями рифея и венда, в меньшей степени карбонатными и терригенными осадками палеозоя и кайнозоя. Мощность осадочного чехла варьирует от $3-4$ км в понижениях дорифейского рельефа до 0,5-1,1 км на возвышенных участках.

Гидрогеологические условия характеризуются распространением на локальной площади водоносных горизонтов четвертичного возраста и повсеместным развитием мощной толщи моноклинально залегающих водоносных горизонтов палеозойского и верхнепротерозойского возраста.

Четвертичные подразделения развиты преимущественно в палеодолинах и депрессиях дочетвертичного рельефа в песчано-глинистых морских, ледниковых, флювиогляциальных и озерно-аллювиальных отложениях с коэффициентом фильтрации от 0,01 до 2,3 м/сут.

Палеозойские подразделения представлены среднекаменноугольными карбонатными образованиями безнапорного олмугско-окуневского горизонта и слабонапорными обводненными песчаниками урзугско-воереченского комплекса.

Олмугско-окуневский водоносный горизонт распространен в карбонатных породах (известковистые доломиты, доломиты) повсеместно, за исключением эрозионной впадины, линейно вытянутой вдоль озер Черное, Волчьи, суммарной мощностью от 11 до $26 \mathrm{м}$.

Урзугско-воереченский водоносный комплекс приурочен к терригенным породам (аргиллиты, алевропесчаники, песчаники) мощностью обводненной толщи от 20 до $46 \mathrm{~m}$, размыт в долине р. Кукомка - оз. Черное.

Среднекаменноугольные отложения отличаются относительно высокими фильтрационными свойствами: коэффициент фильтрации 2-10 м/сут и более.

Верхнепротерозойские подразделения представлены высоконапорными терригенными отложениями падунской и мезенской свит венда.

Падунский водоносный комплекс залегает в мелко- и среднезернистых песчаниках с прослоями аргиллитов и алевролитов. Водопроводимость отложений характеризуется значениями 209-238 $\mathrm{m}^{2} /$ сут, коэффициент фильтрации 1,2-1,8 м/сут .

Мезенский слабоводоносный комплекс приурочен к аргиллитам, алевролитам и песчаникам, обладает слабой водообильностью: водопроводимость пород изменяется в пределах 5,3-11,4 м²/сут, коэффициент фильтрации - 0,02-0,04 м/сут.
На месторождении принят поверхностный способ отработки, при котором осушению подвергается вся толща пород, залегающих над рабочим пластом: олмугско-окуневский и урзугско-воереченский водоносные горизонты, падунский и мезенский водоносные комплексы. $K$ настоящему времени (2018 г.) карьером вскрыты среднекаменноугольные и падунские отложения, вскрытие мезенских образований намечается в 2019 г.

Водопритоки к дренажной системе карьера формируются за счет подземных вод и атмосферных осадков в зоне с активной гидравлической взаимосвязью подземных и поверхностных вод.

Разработка месторождения осуществляется под защитой дренажного контура водопонижающих скважин (ВПС) и карьерного водоотлива.

Контурный ряд водопонижающих скважин насчитывает 75 скважин, оборудованных на падунский водоносный комплекс, и 11 скважин, сооруженных в долине осушенной части озера Черного и оборудованных на четвертичный водоносный горизонт и верхнюю часть падунского водоносного комплекса. Водопонижающие скважины, как правило, обладают относительно высокой производительностью (70-120 $\mathrm{m}^{3} /$ ч), лишь в отдельных скважинах дебит составляет менее $50 \mathrm{~m}^{3} /$ ч.

В настоящее время суммарный объем дренажных вод, откачиваемый водопонижающими скважинами, изменяется в пределах 5000-7000 м³ объем дренажных вод, отбираемых системой карьерного водоотлива - от 700 до $1000 \mathrm{~m}^{3} /$ ч. Общий водоотбор составляет 5900-7600 м³ $/$ ч.

\section{Численная модель фильтрации подземных вод}

Для управляемого водопонижения на карьере разработана численная гидродинамическая модель фильтрации подземных вод, которая учитывает все основные технологические элементы дренажной системы, расположение объекта в зоне активного водообмена подземных и поверхностных водных объектов, данные по выявленным геологическим и гидрогеологическим особенностям месторождения.

Моделирование проводилось с использованием лицензионной программы MODFLOW системы GMS, реализующей пространственную фильтрацию подземных вод методом конечных разностей в многослойной толще для области произвольной конфигурации при наличии фильтрационных неоднородностей в плане и разрезе, инфильтрации (испарения). Программа позволяет определять уровни и понижения уровней подземных вод в каждой узловой точке области фильтрации для каждого слоя, расходы подземных вод в граничных точках изучаемой области, составляющие баланса подземных вод, автоматически управлять работой граничных условий.

Водоносная толща пород реализована в расчетной модели как многослойная, состоящая из четыpex слоев. Верхний слой представлен четвертичными озерно-аллювиальными песчано-глинисты- 
ми отложениями и карбонатными олмугско-окуневскими образованиями. Ко второму слою отнесены урзугско-воереченские песчаники с прослоями аргиллитов. Третий слой включает падунские песчаники с прослоями аргиллитов и алевролитов. За нижний слой принят слабоводоносный мезенский комплекс, представленный аргиллитами и алевролитами с прослоями песчаников.

В соответствии с проведенной схематизацией гидрогеологические условия района характеризуются нестационарным режимом фильтрации пространственного напорно-безнапорного потока подземных вод в многослойном пласте, состоящем из четырех слоев, отличающихся различными фильтрационными параметрами.

Фильтрационный поток исследуемой области моделировался неравномерной прямоугольной сеткой с переменным шагом, изменяющимся от 10 до 100 м, состоящей из $119952(336 \times 357)$ ячеек.

На внешних границах моделируемой области было реализовано ГУ I рода с абсолютными отметками, соответствующими статическому положению уровней подземных вод наиболее водообильного падунского водоносного комплекса (76-115 м), граница проходит за пределами воронки депрессии на расстоянии 6-8 км от контура карьера.

Гидродинамическое несовершенство условий питания или разгрузки подземного потока реками Кукомка, Падун, Ерна и протока Черная учитывалось введением вдоль его русла ГУ III рода с абсолютными отметками уреза воды через дополнительное фильтрационное сопротивление. Отметки дна рек определялись как разница отметок уреза рек и средней их глубины, принятой равной 1 м. При расчете дополнительного сопротивления на реках принимались следующие параметры: коэффициент фильтрации подрусловых отложений равным 0,1-0,01 м/сут, их мощность - 5-10 м, ширина рек - 6-12 м.

Условия питания или разгрузки подземного потока из озер реализовывались на модели ГУ III рода с поддержанием уровня подземных вод на абсолютной отметке, отвечающей отметке фактического заполнения водоема, через дополнительное фильтрационное сопротивление. При расчетах дополнительного сопротивления по площади озер коэффициент фильтрации донных глинистых отложений принимался равным $0,01 \mathrm{~m} /$ сут при средней их мощности 5-10 м.

Условия питания подземного потока из хвостохранилища реализовывались на модели ГУ III рода с поддержанием уровня в прудках на абсолютных отметках, отвечающих средним отметкам фактического заполнения отсеков хвостохранилища за расчетный период, через дополнительное фильтрационное сопротивление.

Определение величины дополнительного фильтрационного сопротивления в каждом конкретном случае выполнялось с учетом вида несовершенства границы по общепринятой в моделировании методике $[4,20]$.
Работа водопонижающих скважин реализована на модели ГУ II рода в соответствии с фактическими данными о среднем водоотборе скважин за расчетный период с учетом несоответствия размеров водопонижающей скважины и блока сеточной модели [23], изменением фильтрационных свойств горных пород в прифильтровой части скважины [20].

Условия разгрузки подземного потока устройствами карьерного водоотлива реализовывались на модели заданием ГУ III рода по отметкам, соответствующим абсолютной отметке подошвы вскрытой части отложений, через дополнительное фильтрационное сопротивление, учитывающее высоту высачивания на бортах карьера.

Инфильтрационное питание атмосферными осадками задавалось равным 0,0003-0,0016 м/сут, исходя из подземного стока порядка $20 \%$ от среднемноголетней интенсивности атмосферных осадков, равной $570 \mathrm{mм} \mathrm{в} \mathrm{год,} \mathrm{что} \mathrm{соответствует}$ $0,0016 \mathrm{~m} /$ сут.

Калибровка модели осуществлялась методом решения обратной задачи, основной целью которой является достижение максимально возможного соответствия построенной фильтрационной модели исследуемому гидрогеологическому объекту: установление соответствия гидрогеологических процессов, протекающих на изучаемом месторождении, их модельным реализациям.

Обратная задача решалась для двух характерных состояний исследуемой гидродинамической системы:

- квазистационарного режима фильтрации подземных вод в период до августа 2012 г.;

- нарушенного режима фильтрации подземных вод в условиях производственного водопонижения за период август 2012 г. - декабрь 2017 г.

В процессе идентификации модели выявлен характер гидравлической связи водоносного комплекса с речными и озерными долинами, определены участки питания и разгрузки водоносных пластов, фильтрационные потери из хвостохранилища Верхотинского ГОКа.

В процессе моделирования установлено, что река Кукомка в нижней части питает водоносные пласты. Инфильтрационные потери из реки составляют $1000 \mathrm{~m}^{3} /$ ч. Реки Падун, Ерна и верхняя часть р. Кукомки дренируют подземные воды, в реки разгружается $1800 \mathrm{~m}^{3} /$ ч подземных вод. Инфильтрация из Волчьих озер достигает $1100 \mathrm{~m}^{3} /$ ч. Фильтрационные потери из озер Черное, Северные и Южные Басурманы не превышают 700 м $^{3} /$ ч. Потери на фильтрацию из хвостохранилища составляют порядка $2000 \mathrm{~m}^{3}$ чч.

\section{Прогнозные расчеты для эффективного} осушения месторождения

Падунские обводненные отложения характеризуются неоднородным литологическим составом, наличием неустойчивых зон слабосцементированных песчаников, находящихся в состоянии, близком к плывунным пескам. 
Сложные гидрогеологические условия месторождения способствовали отставанию процесса осушения от темпов развития горных работ в карьере, формированию бортов карьера в недоосушенной зоне падунских отложений.

Для перехвата части проскока подземных вод в карьер, дренажа падунского водоносного комплекса на участках, где осушение не обеспечивается ВПС, осушение переходной зоны падунских и мезенских отложений предлагается осуществлять горизонтальными дренажными скважинами, сооружаемыми из карьера непосредственно в откос уступа борта карьера или из предварительно пройденного дренажного колодца.
С использованием актуализированной гидродинамической модели проведено прогнозное численное моделирование с целью доказательства принципиальной возможности и эффективности применения системы лучевого дренажа и горизонтальных дренажных скважин в стенку откоса борта карьера для интенсификации процесса осушения падунских отложений в прибортовом массиве карьера. Следует отметить, что до настоящего времени в условиях карьеров Архангельской алмазоносной провинции горизонтальные дренажные скважины для осушения водоносных отложений не применялись.

Оценка водопритоков подземных вод к дренажной системе карьера выполнена при вводе системы

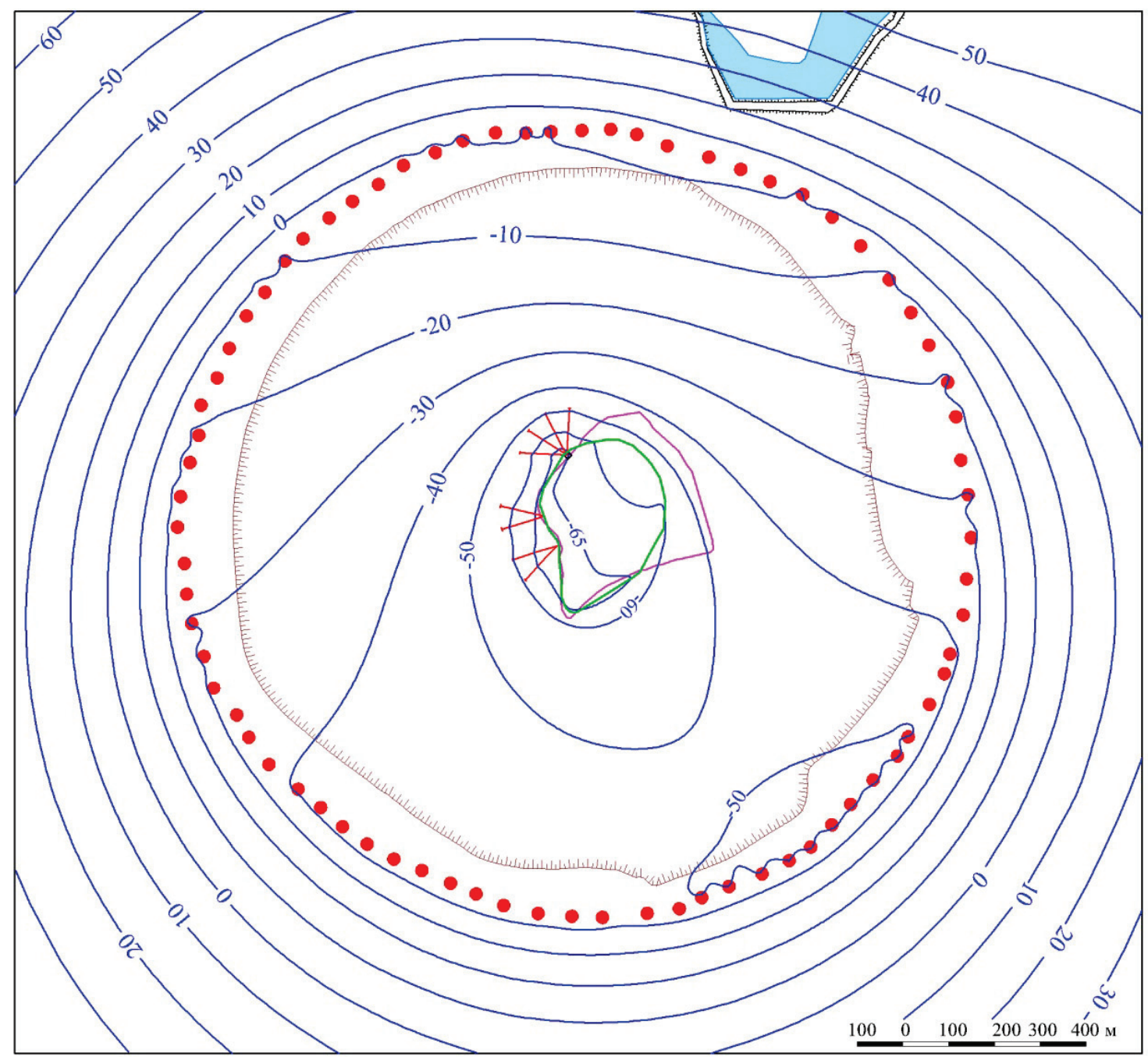

$\{$ контур рудного тела

- водопонижающие скважины

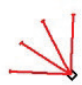

система лучевого дренажа

горизонтальные дренажные скважины в откос борта карьера
Контур карьера

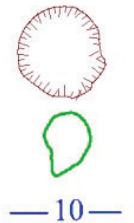

по поверхности

по дну

прогнозный уровень

подземных вод

Puc. 1. Карта прогнозного распределения уровня подземных вод падунского водоносного горизонта на 01.07.2018 2.

Fig. 1. Map of the prognostic distribution of the groundwater level of the Padun aquifer as of 01.07.2018. 
лучевого дренажа (дренажный колодец с 4 лучевыми скважинами длиной по 150 м) и горизонтальными дренажными скважинами в стенку откоса борта карьера (4 скважины длиной по $150 \mathrm{~m})$.

Предложена методика реализации на численной модели внутрикарьерных дрен. Условия разгрузки подземного потока внутрикарьерными устройствами реализовывались на модели заданием ГУ III рода с поддержанием уровня подземных вод на абсолютной отметке, отвечающей глубине заложения лучевого дренажа и горизонтальных дренажных скважин в откос борта карьера, через дополнительное фильтрационное сопротивление, учитывающее несовершенство стока на плановой модели и несоответствие размеров блока модели и радиуса скважины.

Дополнительное фильтрационное сопротивление, учитывающее несовершенство стока на плановой модели, рассчитывалось по зависимости [20]

$$
\Phi_{\text {д }}=\frac{1}{4 \pi k}\left(\frac{\frac{1}{r_{c}}+\frac{1}{2 z_{0}}-\frac{2}{m} \ln m}{r_{\text {с }}}+\Delta \Phi_{\text {д }}\right),
$$

где $k$ - коэффициент фильтрации; $r_{c}$ - радиус скважины; $z_{0}$ - расстояние от подошвы пласта до отметки заложения горизонтальной скважины; $m$ мощность пласта; $\Delta \Phi_{\text {д }}$ дополнительное сопротивление на несоответствие размеров блоков $\Delta x, \Delta y$ и радиуса скважины, определяемое по формуле [23]

$$
\Delta \Phi_{\text {д }}=\frac{1}{k m}\left(\frac{1}{2 \pi} \ln \sqrt{\frac{\Delta x \Delta y}{r_{c}}}-0,25\right) .
$$

Результаты прогнозного моделирования приводятся в табл. 1 и на рис. $1,2$.

Таблица 1. Прогнозные водопритоки к дренажной системе карьера

Table 1. Prognostic water inflows to the drainage system of the

\begin{tabular}{|c|c|c|c|c|c|c|}
\hline \multirow{2}{*}{ 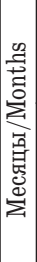 } & \multicolumn{4}{|c|}{$\begin{array}{c}\text { Водоприток, } \mathrm{m}^{3} / ч \\
\text { Water inflow, } \mathrm{m}^{3} / \mathrm{hr}\end{array}$} & \multicolumn{2}{|c|}{$\begin{array}{c}\text { Водоотбор, } \text { м }^{3} / \text { ч } \\
\text { Water with- } \\
\text { drawal, } \mathrm{m}^{3} / \mathrm{hr}\end{array}$} \\
\hline & \begin{tabular}{|l} 
к лучевому \\
дренажу \\
to radiation \\
drainage
\end{tabular} & $\begin{array}{c}\text { к горизонталь- } \\
\text { ным дренаж- } \\
\text { ным скважинам } \\
\text { to horizontal } \\
\text { drainage wells }\end{array}$ & $\begin{array}{c}\text { к карьерному } \\
\text { водоотливу } \\
\text { to career } \\
\text { dewatering }\end{array}$ & 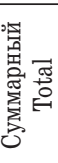 & $\begin{array}{c}\text { ВПС } \\
\text { external } \\
\text { drainage } \\
\text { circuit }\end{array}$ & 䀡 \\
\hline 2 & 259 & 129 & 575 & 963 & \multirow{6}{*}{6850} & 7813 \\
\hline 4 & 247 & 119 & 597 & 963 & & 7813 \\
\hline 6 & 238 & 111 & 614 & 963 & & 7813 \\
\hline 8 & 230 & 104 & 635 & 969 & & 7819 \\
\hline 10 & 223 & 97 & 657 & 977 & & 7827 \\
\hline 12 & 216 & 91 & 680 & 987 & & 7837 \\
\hline
\end{tabular}
quarry

По данным моделирования прогнозный водоприток к лучевому дренажу изменяется в пределах 259-216 $\mathrm{m}^{3} /$ ч, к горизонтальным дренажным скважинам - 129-91 м³ $/$ ч, к карьерному водоотливу от 963 до $987 \mathrm{~m}^{3} /$ ч. Общий водоприток к системе дренажа карьера (с ВПС) не превысит $7840 \mathrm{~m}^{3} /$ ч.
Анализ результатов моделирования показывает, что использование внутрикарьерных дренажных устройств приводит к значительному снижению (на 20- 25 м) высоты высачивания на борту карьера в зоне влияния дренажа, наблюдается снижение уровня подземных вод падунского водоносного горизонта на 2,5-10,0 м в районе внешнего дренажного контура ВПС.

С использованием гидродинамической модели выполнен прогнозный расчет высоты высачивания на бортах карьера с учетом развития карьера в плане и разрезе. Максимальная высота высачивания, при которой возможна потеря устойчивости борта карьера, составляет 75 м.

Прогнозное моделирование проводилось по двум вариантам:

1) водоотбор ВПС $Q=6850 \mathrm{~m}^{3} /$ ч по средней производительности за 2017 г.;

2) водоотбор ВПС $Q=6500 \mathrm{~m}^{3} /$ ч по прогнозной производительности, допускающей уменьшение величины водоотбора.

В каждом варианте расчеты выполнялись по двум подвариантам:

a) коэффициент фильтрации падунских отложений по всей толще $k=1,6 \mathrm{~m} /$ сут;

б) коэффициент фильтрации падунских отложений в верхней части $k=1,6 \mathrm{~m} / \mathrm{cyт}$, в нижней части (мощность около $20 \mathrm{~m}$ ) - $k=0,8 \mathrm{~m} /$ сут.

Результаты прогнозных расчетов высоты высачивания на откосах карьера приводятся в табл. 2.

Таблица 2. Прогнозная высота высачивания на откосах карьера

\begin{tabular}{|c|c|c|c|c|c|c|c|c|c|}
\hline \multirow{3}{*}{$\begin{array}{l}\text { Дата } \\
\text { Date }\end{array}$} & \multirow{3}{*}{$\begin{array}{c}\text { Отметка } \\
\text { дна карье- } \\
\text { pa, м абс. } \\
\text { Mark of } \\
\text { the quarry } \\
\text { bottom, } \\
\text { m abs. }\end{array}$} & \multicolumn{4}{|c|}{$\begin{array}{c}\text { Водоприток к карьерному } \\
\text { водоотливу, } \mathrm{M}^{3} / \text { ч } \\
\text { Water inflow to quarry } \\
\text { drainage, } \mathrm{m}^{3} / \mathrm{hr}\end{array}$} & \multicolumn{4}{|c|}{$\begin{array}{c}\text { Высота } \\
\text { высачивания, м } \\
\text { Seizure height, m }\end{array}$} \\
\hline & & \multicolumn{8}{|c|}{ Вариант расчета/Variant of calculation } \\
\hline & & $\begin{array}{c}1 \mathrm{a} \\
\text { (1a) }\end{array}$ & $\begin{array}{c}16 \\
(1 \mathrm{~b})\end{array}$ & \begin{tabular}{|c|}
$2 \mathrm{a}$ \\
$(2 \mathrm{a})$
\end{tabular} & $\begin{array}{c}2 \sigma \\
(2 \mathrm{~b})\end{array}$ & $\begin{array}{c}1 \mathrm{a} \\
(1 \mathrm{a})\end{array}$ & $\begin{array}{c}16 \\
(1 b)\end{array}$ & \begin{tabular}{|c|}
$2 a$ \\
$(2 a)$
\end{tabular} & \\
\hline .01 & & 950 & 840 & 1030 & 900 & 60 & 70 & 70 & 7 \\
\hline 1.06 .2019 & & 1000 & 900 & 1090 & 970 & 65 & 73 & & 78 \\
\hline
\end{tabular}
Table 2. Prognostic height of seepage on the slopes of the quarry

Анализ результатов моделирования показывает, что при отработке карьера до отметки $-125 \mathrm{M}$ абс. (варианты 16 и 2а) высота высачивания на бортах карьера на 2 м ниже критического значения, при отработке карьера до отметки -115 м абс. (вариант 2б) она достигнет критического значения, а при отработке карьера до отметки -125 м абс. превысит критическое значение на 3 м.

В данных расчетах принято залегание подошвы падунских отложений по условной границе с отметкой -125 м абс. Если граница окажется ниже, то достижение высоты высачивания значения 75 м может быть достигнуто в первой половине 2019 г., а это предполагает, что технические мероприятия по сооружению внутрикарьерных дренажных устройств должны быть реализованы во второй половине 2018 г., чтобы не допустить опасного наращивания высоты высачивания подземных вод в карьере. 
H, м абс.

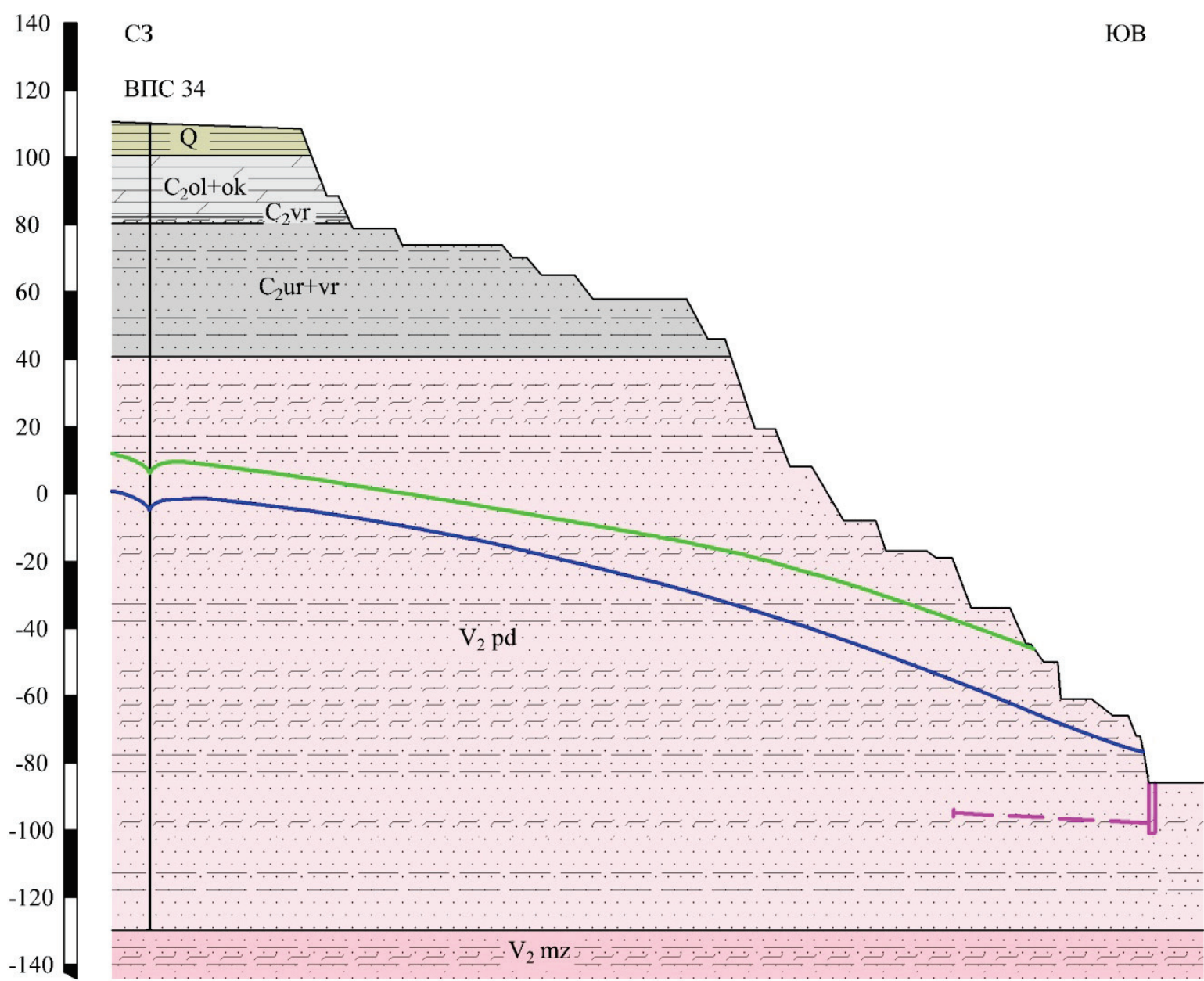

Q Суглинки, супеси, с включением гравия и гальки

Доломиты выветрелые до $\mathrm{C}_{2} \mathrm{Ol}+\mathrm{ok}$ состояния муки, с прослоями крепких разностей, местами окремненные

$\because \stackrel{\sim}{\sim} \sim$

Алевролиты, песчаники

Уровень подземных вод падунского водоносного горизонта

$$
\text { на } 01.01 .2018 \text { г. }
$$$$
\text { на 01.07.2018 г. }
$$

Pис. 2. Гидрогеологический разрез через лучевой дренаж

Fig. 2. Hydrogeological section through radial drainage

\section{Заключение}

С целью перехвата части проскока подземных вод в карьер осушение переходной зоны падунских и мезенских отложений предложено осуществлять внутрикарьерными горизонтальными устройствами.
Песчаник мелкозернистый,

кварцевый, с прослоями аргиллитов; песчаник мелко-среднезернистый, слабосцементированный, часто разрушенный до песка

$-\mathrm{V}_{2} \mathrm{pd}-$ Песчаник мелкозернистый, с прослоями аргиллита, алевролита

$\mathrm{V}_{2} \mathrm{mz} \quad$ Аргиллиты, алевролиты с прослоями песчаников

Лучевой дренаж
Выполнено прогнозное численное моделирование доказательства принципиальной возможности и эффективности применения системы лучевого дренажа и горизонтальных дренажных скважин в стенку откоса борта карьера для интенсификации 
процесса осушения падунских отложений в прибортовом массиве карьера.

Предложена методика реализации на численной модели внутрикарьерных дрен ГУ III рода с поддержанием уровня подземных вод на отметке, отвечающей глубине заложения лучевого дренажа и горизонтальных дренажных скважин в откос борта карьера, через дополнительное фильтрационное сопротивление, учитывающее несовершенство стока на плановой модели и несоответствие размеров блока модели и радиуса скважины.

Прогнозный водоприток к лучевому дренажу изменяется от 259 до $216 \mathrm{~m}^{3}$ чч, к горизонтальным дренажным скважинам - от 129 до $91 \mathrm{~m}^{3} /$ ч, к карьерному водоотливу - от 963 до $987 \mathrm{~m}^{3} /$ ч. Общий водоприток к системе дренажа карьера $\left(Q_{\mathrm{B \Pi C}}=6850 \mathrm{~m}^{3} /\right.$ ч) не превысит $7840 \mathrm{~m}^{3} /$ ч.

\section{СПИСОК ЛИТЕРАТУРЫ}

1. Ломакин Е.А., Мироненко В.А., Шестаков В.М. Численное моделирование геофильтрации. - М.: Недра, 1988. - 228 с.

2. Гавич И.К. Теория и практика применения моделирования в гидрогеологии. - М.: Недра, 1980. - 358 с.

3. Лукнер Л., Шестаков В.М. Моделирование геофильтрации. М.: Недра, 1976. - 407 с.

4. Жернов И.Е., Шестаков В.М. Моделирование фильтрации подземных вод. - М.: Недра, 1971. - 226 с.

5. Jadwiga R.Z., Jeffrey M.P. Competition for water resources. Experiences and Management Approaches in the US and Europe. St. Paul, Minnesota: Elsevier, 2016. - 460 p.

6. Anderson M.P., Woessner W.W. Applied Groundwater Modeling. - San Diego: Academic Press, 2015. - 564 p.

7. Zekai Sen. Practical and Applied Hydrogeology. - Oxford: Elsevier, 2015. $-406 \mathrm{p}$.

8. Smith L. Hydrogeology. Encyclopedia of Physical Science and Technology ( $3^{\text {rd }}$ ed.). - Vancouver, BC, Canada: University of British Columbia, 2015. - $406 \mathrm{p}$

9. Xing Zhang, Sanderson D.J. Numerical Modelling and Analysis of Fluid Flow and Deformation of Fractured Rock Masses. - London, UK: Imperial College London, 2002. - 288 p.

10. Beale G. Hydrogeological model // Guidelines for Open Pit Design / Eds. J. Read, P. Stacey. - Melbourne: CSIR0 Publishing, 2010. P. 141-199.

11. Guidelines for groundwater modelling in open pit mine design / J. Hazzard, B. Damjanac, L. Lorig, C. Detournay // Slope Stability 2011 / Eds. E. Eberhardt, D. Stead. - Vancouver, Canada: Canadian Rock Mechanics Association, 2011. - P. 114-126.

12. Barenblatt G.I., Entov V.M., Ryzhik V.M. Theory of Fluid Flows through Natural Rocks (Theory and Applications of Transport in Porous Media). $1^{\text {st }}$ ed. - Germany: Springer, 2011. - 412 p.
Выполнен расчет прогнозной высоты высачивания на бортах карьера с учетом развития карьера в плане и разрезе. При отработке карьера до отметки -125 м абс. высота высачивания превысит критическое значение на 3 м при условии, когда коэффициент фильтрации падунских отложений в верхней части равен $k=1,6$ м/сут, в нижней части (мощность около $20 \mathrm{~m}$ ) $-k=0,8 \mathrm{M} /$ сут.

Для недопущения опасного наращивания высоты высачивания подземных вод в карьере технические мероприятия по сооружению внутрикарьерных дренажных устройств должны быть реализованы во второй половине 2018 г., поскольку подошва залегания падунских отложений может оказаться ниже расчетной отметки $-125 \mathrm{~m}$ абс.

13. Sahimi M. Flow and Transport in Porous Media and Fractured Rock. $2^{\text {nd }}$ ed. - Weinheim: Wiley, 2011, -709 p.

14. Su Y., Davidson J.H. Modeling Approaches to Natural Convection in Porous Media. - Cham; Heidelberg; New York; Dordrecht; London: Springer, 2015. $-47 \mathrm{p}$.

15. Depner J.S., Rasmussen T.C. Hydrodynamics of Time-Periodic Groundwater Flow - Diffusion Waves in Porous Media. - New York: Wiley AGU, 2017. - $324 \mathrm{p}$.

16. Szymkiewicz A. Modelling Water Flow in Unsaturated Porous Media: Accounting for Nonlinear Permeability and Material Heterogeneity. - Berlin Heidelberg: Springer-Verlag, 2014. $237 \mathrm{p}$.

17. Simulation of Flow in Porous Media Applications in Energy and Environment / P. Bastian, J. Kraus, R. Scheichl, M. Wheeler. Germany: Walter de Gruyter, 2013. - 222 p.

18. Норватов Ю.А. Изучение и прогноз техногенного режима подземных вод (при освоении месторождений полезных ископаемых). - М.: Недра, 1988. - 261 с.

19. Шестаков В.М. Динамика подземных вод. - М.: Изд-во МГУ, 1979. -368 c

20. Фисун Н.В., Ленченко Н.Н. Динамика подземных вод. - М.: Научный мир, 2016. - 268 с.

21. Архангельская алмазоносная провинция (геология, петрография, геохимия и минералогия) / О.А. Богатиков, В.К. Гаранин, В.А. Кононова и др. - М.: Изд-во МГУ, 1999. - 524 с.

22. Харькив А.Д., Зинчук Н.Н., Крючков А.И. Коренные месторождения алмазов мира. - М.: Недра, 1998. - 555 с.

23. Топчий Г.Е. Методическое пособие по применению сеточных электроинтеграторов для решения задач неустановившейся фильтрации подземных вод. - Белгород: Изд-во ВИОГЕМ, 1971. -56 c.

\section{Информация об авторах}

Еланиева Л.А., кандидат геолого-минералогических наук, заведующий научным отделом ООО НТЦ «НОВОТЭК» .

Зайцев Д.А., кандидат технических наук, главный инженер проектов ООО НТЦ «НОВОТЭК».

Фоменко C.B., научный сотрудник ООО НТЦ «НОВОТЭК». 
UDC 556.3.06

\title{
HYDROGEOLOGICAL FORECASTS FOR DEWATERING DIAMOND DEPOSIT NAMED AFTER V. GRIB
}

\author{
Lyudmila A. Elantseva', \\ LAElanceva@novotek15.ru
}

Denis A. Zaitsev',

Zden86@yandex.ru

\section{Sergey V. Fomenko',}

SVFomenko@rambler.ru

1 NEWTECH Co., Ltd (OOO NTC NOVOTEK),
131, B. Khmelnitskogo avenue, Belgorod, 308002, Russia.

The relevance of the research is caused by the need to involve in industrial using a diamond deposit, very complicated from hydrogeological point of view, in which ore production is carried out with important dewatering activities aimed to create a safe mining conditions. Forecasting the managed dewatering and changes in hydro-geological conditions during deposit exploitation is a complex problem, which requires a consideration of many natural and mining factors and development of methodical approach for its solution.

The main aim of the research is to develop the methodology and implement the hydro-geological forecasts for effective draining during exploitation of diamond deposit named after V. Grib.

Objects: drained aquifers and drainage system of open pit.

Methods: analysis of using the numerical modeling methods for studying groundwater filtration during dewatering of mineral deposits, numerical modeling.

Results. Based on the study of geological and hydrogeological conditions of the diamond deposit named after V. Grib, method of development, drained aquifers, sources of formation of water inflows to the drainage system of the open pit, the numerical model of groundwater filtration have created. In order to drainage of the Padun aquiferous complex at sites where dewatering is not ensured by pumping wells it is recommended to intercept a part of groundwater penetrating into the open pit by means of a drainage devices inside the open pit for dewatering transitional zone between Padun and Mezen sedimentations. The authors proposed the technique for implementing drains inside the open pit in numerical model and carried out the prognosing calculations for effective drainage of the deposit. Using the numerical modeling method the authors proved the efficiency of applying radial drains and horizontal drainage wells to intensify dewatering of the Padun sedimentations in rock massif near the open pit border. The forecast calculations were performed for estimation of seepage height inside the open pit taking into account the mining plan. The timing of drainage devices construction inside the open pit was substantiated.

\section{Key words:}

Managed dewatering, pumping wells, open pit drainage, hydrogeological forecasts,

numerical modeling, radial drainage, horizontal drainage wells.

\section{REFERENCES}

1. Lomakin E.A. Mironenko V.A. Shestakov V.M. Chislennoe modelirovanie geofiltratsii [Numerical modeling of geofiltration]. Moscow, Nedra Publ., 1988. 228 p.

2. Gavich I.K. Teoriya i praktika primeneniya modelirovaniya $v$ gidrogeologii [Theory and practice of modeling application in hydrogeology]. Moscow, Nedra Publ., 1980. 358 p.

3. Lukner L., Shestakov V.M. Modelirovanie geofiltratsii [Modeling of geofiltration]. Moscow, Nedra Publ., 1976. 407 p.

4. Zhernov I.E., Shestakov V.M. Modelirovanie filtratsii podzemnykh vod [Modelling of groundwater filtration]. Moscow, Nedra Publ., 1971. 226 p.

5. Jadwiga R.Z., Jeffrey M.P. Competition for water resources. Experiences and Management Approaches in the US and Europe. St. Paul, Minnesota, Elsevier, 2016. 460 p.

6. Anderson M.P., Woessner W.W. Applied Groundwater Modeling. San Diego, Academic Press, 2015. 564 p.

7. Zekai Sen. Practical and Applied Hydrogeology. 0xford, Elsevier, 2015. $406 \mathrm{p}$.

8. Smith L. Hydrogeology. Encyclopedia of Physical Science and Technology. ${ }^{\text {rd }}$ ed. Vancouver, BC, Canada, University of British Columbia, 2015. $406 \mathrm{p}$.

9. Xing Zhang, Sanderson D.J. Numerical Modelling and Analysis of Fluid Flow and Deformation of Fractured Rock Masses. London, UK, Imperial College London, 2002. 288 p.
10. Beale G. Hydrogeological model. Guidelines for Open Pit Design. Eds. J. Read, P. Stacey. Melbourne, CSIR0 Publishing, 2010. pp. 141-199.

11. Hazzard J., Damjanac B., Lorig L., Detournay C. Guidelines for groundwater modelling in open pit mine design. Slope Stability 2011. Eds. E. Eberhardt, D. Stead. Vancouver, Canada, Canadian Rock Mechanics Association, 2011. pp. 114-126.

12. Barenblatt G.I., Entov V.M., Ryzhik V.M. Theory of Fluid Flows through Natural Rocks (Theory and Applications of Transport in Porous Media). $1^{\text {st }}$ ed. Germany, Springer, 2011. 412 p.

13. Sahimi M. Flow and Transport in Porous Media and Fractured Rock. $2^{\text {nd }}$ ed. Weinheim, Wiley, 2011. 709 p.

14. Su Y., Davidson J.H. Modeling Approaches to Natural Convection in Porous Media. Cham; Heidelberg; New York; Dordrecht; London, Springer, 2015. 47 p.

15. Depner J.S., Rasmussen T.C. Hydrodynamics of Time-Periodic Groundwater Flow - Diffusion Waves in Porous Media. New York, Wiley AGU, 2017. 324 p.

16. Szymkiewicz A. Modelling Water Flow in Unsaturated Porous Media: Accounting for Nonlinear Permeability and Material Heterogeneity. Berlin, Heidelberg, Springer-Verlag, 2014. 237 p.

17. Bastian P., Kraus J., Scheichl R., Wheeler M. Simulation of Flow in Porous Media Applications in Energy and Environment. Germany, Walter de Gruyter, 2013. 222 p.

18. Norvatov Yu.A. Izuchenie i prognoz tekhnogennogo rezhima podzemnykh vod pri osvoenii mestorozhdenii poleznykh iskopaemykh 
[The study and forecast of the technogenic regime of groundwater (with the development of mineral deposits)]. Moscow, Nedra Publ., 1988. $261 \mathrm{p}$.

19. Shestakov V.M. Dinamika podzemnykh vod [The dynamics of groundwater]. Moscow, MSU Publ., 1979. 368 p.

20. Fisun N.V., Lenchenko N.N. Dinamika podzemnykh vod [The dynamics of groundwater]. Moscow, Nauchny mir Publ., 2016. $268 \mathrm{p}$.

21. Bogatikov 0.A., Garanin V.K., Kononova V.A. Arkhangelskaya almazonosnaya provintsiya, geologiya, petrografiya, geokhimiya mineralogiya [Arkhangelsk diamondiferous province (geology, petrography, geochemistry and mineralogy)]. Moscow, MSU Publ., 1999. 524 p.
22. Kharkiv A.D., Zinchuk N.N., Kryuchkov A.I. Korennye mestorozhdeniya almazov mira [Primary deposit of diamonds of the world]. Moscow, Nedra Publ., 1998. 555 p.

23. Topchii G.E. Metodicheskoe posobie po primeneniyu setochnykh elektrointegratorov dlya resheniya zadach neustanovivsheisya filtratsii podzemnykh vod [Methodical manual on the application of grid electrointegrators for solving the problems of unsteady groundwater filtration]. Belgorod, VIOGEM Publ., 1971. 56 p.

Received: 5 September 2018.

\section{Information about the authors}

Lyudmila A. Elantseva, Cand. Sc., head of scientific department NEWTECH Co., Ltd (OOO NTC NOVOTEK).

Denis A. Zaitsev, Cand. Sc., chief project engineer NEWTECH Co., Ltd (OOO NTC NOVOTEK).

Sergey $V$. Fomenko, research officer chief project engineer NEWTECH Co., Ltd (OOO NTC NOVOTEK). 